\title{
The Effect of Task-Based Language Teaching on Developing Students' Oral English Achievement: With Reference to Damot Preparatory School Grade Eleven Students
}

\author{
Mohammed Seid Kebede \\ Mekidela Amba University College of Common Courses Department of English, Ethiopia
}

\begin{abstract}
The main aim of the present study was to investigate the effect of task based language teaching in developing oral English achievement of Demot Higher Education and preparatory School grade 11students. To achieve this objective ,a task-based language teaching program was prepared based on grade 11 English textbook. An oral achievement test with an assessment rubric was administered. Two independent groups of Damot preparatory school students were selected by purposive sampling for experimentation. One class representing the experimental group learned through the task-based language teaching while the other one class representing the control group learned the same part following the traditional/ regular teaching methodology. Oral performance test was used as an instrument. Data were analyzed using SPSS using independent sample t-test and paired sample t-test. Results revealed that there were statistically significant differences between the mean scores of the experimental and control subjects on their oral English achievement in favor of the experimental group. Results also showed statistically significant difference between mean scores of experimental group subjects in the paired sample t-test of their pre-post test scores of oral English achievement in favor of the post test. These results support that using task-based language teaching is effective in developing students' oral achievement and build self-confidence.

Key words/ phrases: Task-based language teaching; traditional /regular instruction; oral achievement; $t$-test; independent sample; paired sample
\end{abstract}

DOI: $10.7176 /$ JLLL/75-03

Publication date: January $31^{\text {st }} 2021$

\section{CHAPTER ONE}

\section{INTRODUCTION}

Speaking is one important language skill among the four basic skills. As Brown (2007), speaking is an interactive process of constructing meaning that involves producing, receiving and processing information. Its form and meaning are dependent on the context in which it occurs, including the participants themselves, their collective experiences, the physical environment, and the purpose of speaking. It is often spontaneous, open-ended, and evolving. But, speech is not always unpredictable. (Burns,1997). Speaking requires that learners not only know how to produce specific points of language such as grammar, pronunciation, or vocabulary, but also that they understand when, why and in what ways to produce language.

Speaker's skills and speech habits have an impact on the success of any exchange. Speakers must be able to anticipate and then produce the expected patterns of specific discourse situations. They must also manage discrete elements such as turn-taking, rephrasing, providing feedback, or redirecting van Duzer (1997).

A lot of methods and approaches have been used for foreign language teaching. Until the middle of $20^{\text {th }}$ century, grammar translation method was dominant. Then due to the paradigm changes in psychology and linguistics a scientific revolution occurred in the language teaching and many different methods were proposed each of which paid attention to different skills. Then the communicative language teaching (CLT) emerged in 1980(Baghar,S.,2014).

This emphasis on making meaning the priority in syllabus design and methodology underlies many aspects of contemporary approaches to language teaching, for example, communicative Language teaching, Task-Based Language Teaching. Language acquisition research suggests that overwhelmingly that language learning is a developmental process, which cannot be consciously controlled or predicted by teachers or learners. It seems that language learning in the sense of acquiring the ability to use the language spontaneously is powerful driven by natural process. But it also seems that these processes can be sharpened and rendered more efficiently by an appropriate focus on form. Task-Based Learning (TBL) represents an attempt to harness natural process and to provide language focus activities based on consciousness-raising which support these processes(Willis, 1996).

One of the most important phenomenon of language learning-teaching process is to make students reach the intended language level in a shorter time in a better way. So, the practice of Task Based Language Teaching in English is gaining importance now days. Teaching methods are the application of theoretical findings and positions Brown (1991).

According to (Larsen-Freeman, 2000).Task-Based Language Teaching is an approach seeking to provide learners with a natural context for language use. As learners work to complete a task, they have abundant 
opportunity to interact. Such interaction is thought to facilitate language acquisition as learners have to work to understand each other and to express their own meanings.

Language learning entails both conscious and unconscious acquisition of not only receptive skills such as listening and reading and also productive skills such as speaking and writing. The skills must be well integrated within the course syllabus in order to enable the learners to have a good command of the target language (Doff, 1998; Nunan,1998; and Woodward,1991).

Teachers of English tend to stress drilling patterns, reading texts and writing tasks, but rarely have their students involved in speaking activities. But learning to speak in English is more effectively achieved by speaking than listening and reading. In the school where the researcher is working, English language teaching and learning follow the traditional grammar focused method. In English language classrooms, the focus is on grammatical rules, memorization of vocabulary and phrases, translation of texts and doing reading completion exercises.

Some researchers place the possibilities of teaching speaking successfully up on teaching techniques. There are many strategies that can be used by teachers in English as foreign language contexts to help learners develop their speaking skill. Shu mine (1997) suggests that learners should develop short, interactional exchanges in which they are required to make short utterances. It will make them able to become more engaged in a small talk in the target language.

Having the above discussions, and based on the researcher's experience of Damot preparatory school classrooms, it has become clear that the techniques utilized in teaching English are competitive and test driven. Students are encouraged to learn what will come in exams. They learn to copy down and memorize phrases which help for oral communication on behalf of writing. This can show us learning for communication or sharing one's knowledge with others in the class has no place in the English language classroom. It has also been noticed that the majority of the students in English classrooms are passive recipients and they rarely take the initiative for participation.

EFL speaking skills are were not practiced well in Damot Preparatory School classes, which leads to the observable shortage in students' ability to communicate. This was because teachers' over emphasis on accuracy, grammatical correctness, the limited evaluation system and most importantly the methods of teaching adopted that do not motivate students to use the language involuntarily. The above discussions highlighted the need for adopting better teaching techniques to develop Damot Preparatory School students' English oral achievement. These considerations implied that the attempt to address the problems of the students' weakness in speaking through applying TBLT as an effective approach to develop Damot Preparatory School grade 11 students' oral English achievement.

To the researcher's knowledge, there are no studies which have been devoted to studying the effectiveness of task based language learning/teaching on developing students' oral performance in Ethiopian context. Therefore, this research aims to investigate the effect of TBLL on developing students' oral performance with respect to Damot preparatory school grade 11 students.

Therefore, the problem of the study is concerned on the fact that Damot Preparatory School grade 11 students are incompetent in the speaking skill and suffers from the ability to express themselves orally in English. So, the need for language teaching that encourages students to use English communicatively is needed. Language activities should encourage learners to participate actively in English classes. That means learning English should be more self-directed rather than teacher-directed .In this research it is hypothesized that incorporating some TaskBased Language Learning techniques in teaching Damot Preparatory School grade eleven students may improve and promote their oral performance in English.

The present research tried to test the following hypotheses:

1. There is no statistically significant difference between mean scores of the experimental group subjects exposed to the suggested TBLT program, and the control group subjects received the regular instruction on the post-test of their oral achievement in favor of the experimental group.

2. There is no statistically significant difference between the mean scores of the experimental group subjects on the speaking pre-test and posttest in favor of post test scores.

Hence, the present study is intended to investigate whether Task-Based Language Teaching (TBLT) can enhance and improve Damot Preparatory school learners", speaking skill.

\section{CHAPTER TWO}

\section{RESEARCH METHODOLOGY}

\subsection{Research Design}

The design of the research was a quasi-experimental research design which is advised to use it where there is no true experiment on human beings. In this study, the two classes were used to represent the experimental and control groups. The study was implemented in the students' natural setting of the two classes. The experimental groups received a task based language teaching for developing their oral achievement; whereas, students in the control group received regular instruction. 


\subsection{Participants of the Study}

A group of eighty grade eleven students were selected from Damot Preparatory school in the school year 2008 E.C. These were two classes with forty students in the experimental group and another forty students in the control group. The reason these two classes were selected in that it was seen a representative sample of Damot preparatory school grade eleven students with a large population of six hundred eighty for the quasi- experimental research. In addition to this, the researcher was an English teacher in these two specified classes. Students' age in both groups ranged from 18-21 years. They had similar cultural background. They have been learning English as a foreign language since grade one. Amharic is their mother tongue. The school had a trend of assigning students in each class based on a fairly distribution of male and female, students' grade 10 matriculation examination results and their grade 9 and grade 10 average. So, the classes under this study constituted a homogenous group. Damot preparatory school students have five periods of English language instruction per a week, each lesson lasts for 42 minutes. Their English language syllabus consists of listening, reading, writing, speaking, grammar and vocabulary.

\subsection{Instruments of the Study}

To achieve the purpose of the study, the researcher used the oral achievement test.

\subsubsection{The Speaking Skills Test/Oral Achievement Test}

A pre-test of oral achievement was constructed and administered by the researcher. It was used before the program was implemented to make sure those students of both experimental and control groups were at the same oral English achievement level before starting the program.

A posttest of oral achievement was constructed and administered by the researcher. It was used at the end of the task based language teaching program. It was used to investigate the effect of task based language teaching program in developing students' oral achievement. In the pretest, participants of both experimental and control groups were given time to present their speech and their scores were scored by the raters based on prepared oral achievement test rubric. In the post- test, the participants were evaluated by the raters based on the oral achievement test rubric in the same way as the pre-test.

The purpose of the speaking test was to assess the participants' speaking skills before and after the implementation of the TBLT program in order to detect the effect of TBLT on the participants' oral English achievement.

The oral achievement test rubric for the participants' oral achievement was used in the study which aimed at assessing the effect of using task based language teaching in teaching eight units speaking lessons. The rubric includes name of the student, group (experimental/control), and speaking skills which are grammar, pronunciation, vocabulary, comprehension/accuracy and fluency.

\subsection{Data Collection Procedure of the Study}

The participants were pre and post-tested orally, and were then evaluated by two EFL teachers according to evaluation rubric presented by the researcher. The test rubric was prepared two copies for each student one for a pre-test and one for the post-test. That means a total of 160 copies of test rubric was prepared for both the experimental and control group students. The evaluation test rubric was evaluated and validated by a group of English teachers of the school. These teachers were 3 M.Ed. holders in TEFL, 3 who were doing their thesis in TEFL, two teachers were $4^{\text {th }}$ summer postgraduate students in TEFL. This validation team had awareness about TBLT; additionally training was given to them in addition to the course they have taken.

The following procedures were carried out for the preparation and administration of the test.

1. The test was prepared by the researcher and validated by groups of English language teachers ( 7 male and 1 female).

2. The researcher and the EFL teachers who carried out the test held a training session in which they discussed the questions in the speaking test and evaluation rubric and agreed on the content and the procedures of the test and its evaluation.

3. The raters held individual sessions with the students who participated in the study. These raters met with each student for a minute in each test session, which they asked the speaking skills test. Each test session was recorded with life player/recorder. After each test session the raters evaluated the students' oral achievement according to the valuation rubric. These procedures were used before and after the implementation of the TBLT program.

\subsection{Hypotheses Testing Techniques}

This study has two hypotheses which were proposed as a major objective of the study. The score differences between pre-test and post-tests of the control and experimental groups were compared by using mean scores, standard deviation, and t-test particularly, independent samples t-test and paired sample t-test.

Both independent sample t-test and paired-sample t-test were used to analyze the oral English achievement test results in the study. Independent sample t-test was used to compare the results of the experimental and control 
groups that were independent of each other.

A paired sample t-test was also employed to compare two sets of scores obtained from the same group or when the same participants are measured more than once at two different times. It was used to compare the test scores before and after the intervention of the students in the experimental groups separately.

\subsection{The Pilot Study}

A pilot study was conducted before the main study to discover any methodological flaws and weaknesses of the research design. More specifically, through piloting the researcher tried to check the adequacy of pre-test and posttest, and classroom observation and to see the practical aspects of administering the data collection tools, including the time required to administer the instrument, the clarity of instructions, and the suitability of methods of data analysis. Pilot studies help researchers to clarify instructions, determine appropriate levels of independent variable, determine the reliability and validity of the methods, and work the bugs out of the procedures (Bordens and Abbott, 2002). To achieve these purposes, a pilot study often involves a small-scale test of the entire study-a testing of not only instruments but also the lesson, the study procedures, and so on (Hughes, 1989). Therefore, an attempt was made to see the reliability, and validity of the instruments.

Its aim was to enhance the validity, reliability and practicability of the present study (Cohen et al., 2000). An experimental design was used, but it was on a smaller scale than in the main study. There was also no control group because the main concern at this stage was to detect any unexpected problems with implementation. The participants of the pilot study were fifteen grade eleven students from one of the classes at Damot Higher Education Preparatory School in the Finote Selam town. The participants had similar characteristics, in terms of age, mother tongue and similar educational background, their grade level to the students whom the researcher would target for the main study. They took an oral achievement pre-test before the intervention. After the intervention, they took a pilot post-test so that the researcher could fine-tune the test according to their answers and responses.

To determine the time, difficulty and suitability of the tasks selected to measure the expected skills, a pilot study of the speaking test was conducted. Fifteen students were randomly selected from Damot preparatory school grade eleven students. These were not belonged to the experimental group or control group students.

From the pilot study, it was gained that students were confused or didn't understand some phrases or expressions; shortage of time was also the major problem. Three minutes for each student was given. It was proved that the test was suitable to students and that the tasks included extract the intended speaking skills.

Based on the pilot study, the examiner took the following points into consideration.

$\checkmark \quad$ Focused on warm up stage to help students feel comfort and relaxed

$\checkmark \quad$ Used easy and clear phrases, omitted some too long and doubtful phrases.

$\checkmark$ Give clear instructions what students were expected to do

In the current study to check test construct validity grammar, vocabulary, pronunciation, accuracy and fluency were reflected in all turns that the examiner took and it was assessed. The students' appropriate uses of vocabulary selection, grammar, and sound pronunciation were assessed. Students' ability to structure their ideas, their ability to maintain a coherent flow of language was assessed. The ability of students that had to respond appropriately was assessed more deeply through providing students with a set of social situations. Fluency was measured in terms of the learner's rate of speech and their ability to communicate in real time without in- appropriate pauses or hesitation.

To measure the test content validity the first version of the test was given to eight EFL teachers in which some were master's degree holders in TEFL and others were on the way to graduate this year in TEFL. They evaluated the test in terms of its content appropriateness and skills it measures. The test evaluators were asked to evaluate the test in terms of number of tasks appropriateness to the functions measured, suitability of the test to Damot preparatory school students' linguistic level and the suitability of the test to measure the intended speaking skills.

Based on the evaluators' comment, the following remarks were highlighted.

$\checkmark \quad$ It was suggested that some too long phrases should be omitted. Only the tasks that reflect closely the situations taught in the experiment/program were included.

$\checkmark$ To ensure authenticity and to avoid cultural or linguistic misunderstanding the content and words used in all tasks were related to learners' culture.

The oral english achievement of students was evaluated by two raters based on the designed rating scale. The rubric of the rating scale was designed based on the identified speaking skills (grammar, pronunciation, accuracy, vocabulary, and fluency). The rubric was prepared containing the above mentioned speaking skills with a rating scale of one to four levels each having 4 indicators. Each skill had a load of 16 (grammar $=4 \times 4=16$, pronunciation $4 \times 4=16$, vocabulary $4 \times 4=16$, accuracy $4 \times 4=16$ and fluency $4 \times 4=16)$. One student was evaluated from a total of $80 \%$ in the above five categories. 


\section{CHAPTER THREE}

\section{DATA ANALYSIS AND INTERPRITATION}

The main purpose of this study was to investigate the effect of task based language teaching in developing Damot preparatory school grade 11 students' oral English achievement. The findings of this study are presented in this chapter by relating them to the study hypotheses.

To control variables before the implementation of the program, the results of the pre-test were analyzed to find whether there were statistically significant differences between the experimental and the control groups in their oral English achievement. An independent sample t-test was used to compare the two groups based on their oral achievement (grammar, pronunciation, vocabulary, accuracy and fluency) and a paired sample t-test were used to compare the mean scores of the experimental group pre-test and posttest scores. This is shown in the following tables.

\section{Table one}

Independent sample t-test results of the pre-test comparing the control group and experimental groups' mean scores in their oral English achievement.

\begin{tabular}{|l|l|l|l|l|l|l|l|}
\hline Group & $\mathrm{N}$ & $\mathrm{M}$ & $\mathrm{SD}$ & $\mathrm{Df}$ & t-value & Sig(2-tailed & Mean difference \\
\hline Control & 40 & 29.4500 & 4.52741 & 78 & .402 & .689 & .41250 \\
\cline { 1 - 4 } Experimental & 40 & 29.0375 & 4.65666 & & & & \\
\hline
\end{tabular}
$\mathrm{P}>.05$

The above table shows that t-value is (.402) which is not statistically significant at 0.05 . Therefore it could be concluded that the two groups were at the same level of achievement in their oral achievement and hence any difference between the two groups that may occur after the implementation of the program will be caused by the intended program. To make sure that there was no statistically significant difference between the two groups on the pre-test in speaking skills; an independent sample t-test for the differences between the experimental and control groups mean scores was conducted.

Table two

Independent sample t-test results of the post-test comparing the control and experimental groups mean scores in oral English achievement.

\begin{tabular}{|l|l|l|l|l|l|l|}
\hline Group & $\mathrm{N}$ & $\mathrm{M}$ & $\mathrm{SD}$ & $\mathrm{Df}$ & t-value & Sig(2-tailed \\
\cline { 1 - 4 } Control & 40 & 39.4375 & 4.10591 & 78 & -23.265 & $\mathbf{. 0 0 0 *}$ \\
\cline { 1 - 4 } Experimental & 40 & 58.5250 & 2.11815 & & & \\
\hline
\end{tabular}

$\mathrm{P}<.05$

Table two above shows that the estimated t-value (23.265) was statistically significant at 0.05 level. Therefore it can be said that there were statistically significant differences between the experimental and control group on the post-test in oral achievement in favor of the experimental group. Hence, the null hypothesis is rejected and the alternative hypothesis is accepted.

To determine the change gained by implementing task-based language program from the pre-test to post-test for the experimental group, a paired sample t-test was used. The paired sample t-test aimed at comparing the mean scores of the experimental group on the pre-test and posttest in their oral achievement.

Table 3

Paired sample t-test results comparing the pre-test and the posttest mean scores for the experimental group oral English achievement.

\begin{tabular}{|l|l|l|l|l|l|l|}
\hline Test & N & M & SD & Df & T-value & Sig(2tailed) \\
\hline Pre-test & 40 & 29.0375 & 4.65666 & 39 & -40.878 & Significant at $(0.05)$ \\
\hline Post-test & 40 & 58.5250 & 2.11815 & & & \\
\hline
\end{tabular}

As it is seen in table(3) above, there are statistically significant differences at(0.05) level in oral achievement between pre-test and post-test mean scores of the experimental group in favor of the post-test scores .

Therefore, it can be said that the paired sample t-tests proved to be statistically inconsistent with the null hypothesis. So, the null hypothesis is rejected and the alternative hypothesis is accepted.

\section{CHAPTER FOUR}

\section{SUMMARY, CONCLUSIONS AND RECOMMENDATIONS}

\subsection{Summary of the Study}

To summarize the major findings of this study, the null hypothesis predicting no significant differences of students' oral English achievement through using task based language teaching for the experimental group and the control group receiving regular instruction was rejected in this study.

There were statistically significant differences at 0.05 levels between the mean scores of the experimental group exposed to the suggested task based language teaching program and the control group receiving regular instruction on the post-test in students' oral English achievement in favor of the experimental group. The analysis 
of the independent sample $\mathrm{t}$-test revealed that $\mathrm{t}=23.265$. Hence, the task based language teaching program contributed to students' oral English development.

There were statistically significant differences at 0.05 level between the mean scores of the experimental group on the speaking pre-test and post-test in oral English achievement in favor of the post-test scores.

\subsection{Conclusion}

Based on the results of the present study, the following conclusions can be made.

- Using awareness raising activities before engaging students in different tasks help students to improve their speaking achievement because it guides/ shows them how communication takes place in real life situations. This idea is supported by Ellis(1991).

- Helping students to plan before speaking and interacting orally proved to be effective in improving students speaking achievement in speaking skills. It can lead learners to users of English to produce better speech. It helps students to ensure that their improvement in their oral achievement is because of their own oral language use and production. This is supported by Skehan(1996) and Ellis(2003).

- The self/peer evaluation after doing tasks helps students to lead and control their own learning because they pay more attention to their strengths and weaknesses. Therefore, it helps them to correct themselves. As it is supported by Skehan(1998) and Willis(1993), this encourages students to be more involved in planning and organize their own learning. The self-evaluation process proved to be more effective when learners are aware of the criteria to which their achievement can be evaluated.

- $\quad$ Providing supportive feedback throughout task cycle is highly effective. During these feedback students strengths in speaking can be seen and admired and possible suggestions for improvements can be given in a way that helps students develop their oral achievement. This can be supported by Skehan(2002).

- The roles taken by students as risk takers of their learning and the teachers' roles as a facilitator, organizer and advisor allows students to share more responsibilities for their learning, express themselves/ideas freely and become the core of the learning process.

To generalize, task based language teaching is effective on developing students' English oral achievement and help them build self-confidence.

\subsection{Recommendation}

Based on the present study the following recommendations are given

- Teaching speaking should be given more attention in our English classes.

- In English classes students, should be given opportunities to practice speaking based on their cultural basis to make it authentic

- Students should be aware of the criteria according to which their speaking achievement is evaluated. This may make them to work hard to fulfill the task based on the give criteria. In addition to this, teachers should have awareness about teaching speaking and designing the criteria for evaluating students speaking achievement in different stages.

- English teachers could see the five speaking skills at the same level and equally. They shouldn't be based on only grammar or vocabulary. Even teachers should teach speaking by making students speak and evaluate them through speaking not through writing. Evaluation of students speaking achievement shouldn't be as a summative evaluation through writing.

- Teachers should use task-based language teaching in teaching their students develop their speaking skills. English language teachers should teach speaking following task based language teaching stages (pre-task stage, during-task stage and post-task stage) appropriately.

- Teachers should make their students to take a risk to their learning to develop their speaking skills. This can make them become more independent and contribute their effort in learning speaking. The teachers should take the role of facilitator, organizer, supporter, and advisors whereas students should be players of different roles(as chair persons, secretary, presenters----)

- Teachers should encourage and appreciate students speaking achievement. This can motivate students to speak their ideas freely.

\section{REFERENCE}

Baghar,S.(2014). The Effect of Task-Based Language Teaching (TBLT) and Content-Based Language teaching(CBLT).Il am University, Il am-Iran.

Bordens, K.S.R., \& Abbott, B.B. (2002). Research design and methods: A proces approach(5 ${ }^{\text {th }}$ ed.). Boston: McGraw-Hill

Brown,R.(1991). "Group work, Task Difference, and Secondary Language Acquisition.” 21:1-12

Cohen, L., Manion, L., and Morrison, k. (2000). Research methods in Education (5th ed.). London: Rutledge 
Falmer Education.

Doff,A.(1998)Teach English. Cambridge University Press.

Ellis,R.(2000). Task-Based Research and Language Pedagogy. Language Teaching Research. Oxford: Oxford University Press.

Ellis,R.(2003). Task-Based Language Learning and Teaching. Oxford University Press,pp.9. Hughes, A. (1989). Testing for Language Teachers. Cambridge: CUP

Larsen-Freeman((2000).Techniques and Principles in language Teaching. Oxford: Oxford University Press. Nunan,D.(1998). Language Teaching Methodology. Prentice Hall International.

Shumine,K.(1997). Factors to Consider: Developing Adult EFL Students' Speaking Abilities. Cambridge: Cambridge University Press .

Skehan,P.(1996). A framework for Implementation of Task-Based Instruction. Applied Linguistics.17,38-62

Willis,J.(1998).TaskBasedLearning;WhatkindofAdventure?Available:http://langue.hyper.chubu.ac.jp/jalt/pub/tlt/ 98/jul/willis, html.

Willis ,J.(1996). A Framework for Task-Based Learning. Harlow: Longman.

Woodward,T.(1991). Models and Metaphors in Language Teachers Training. Cambridge University Press. 